\title{
Rize İlinin Turizm Göstergelerinin Yıllara Göre Türkiye ile Kiyaslanmas1: 2009-2015
}

Doç. Dr. Ahmet TAYFUN Gazi Üniversitesi, Turizm Fakültesi. e-posta: tayfun@gazi.edu.tr

Arş. Gör. Esin AYSEN Gazi Üniversitesi, Turizm Fakültesi. e-posta: esinaysen@gazi.edu.tr

Arş. Gör. Burcu Ayşenur AKBULUT, Recep Tayyip Erdoğan Üniversitesi, Ardeşen Turizm Fakültesi. e-posta: burcuaysenur.akbulut@erdogan.edu.tr

\section{Öz}

Türkiye'nin Karadeniz Bölgesinde yer alan Rize ili; yaylaları, kaplıcaları, akarsuları, şelaleleri, gölleri, flora ve faunası gibi doğal güzelliklerinin yanı sıra geleneksel konutları, kaleleri, taş kemer köprüleri, camileri, müzeleri gibi tarihi-kültürel zenginlikleri açısından da zengin bir turizm potansiyeline sahiptir. Rize'nin sahip olduğu turizm kaynaklarının kullanımı ve bölgeye gelen turistler yıllar içinde değişim göstermektedir. Rize'nin Türkiye turizmi içerisindeki yerini görebilmek ve turizmden aldığ1 payı Türkiye ekseninde değerlendirmek bu çalışmanın esas amacını oluşturmaktadır. Bu doğrultuda yıllara göre Rize'nin turizm göstergelerindeki değişiklikleri ortaya koyarak bu göstergeler ile Türkiye turizmine yönelik istatistikleri kıyaslamak hedeflenmektedir. Rize turizmi; gelen turist sayısı, geceleme miktarı, turistlerin ziyaret amacı, gelir ve eğitim düzeyleri açısından Türkiye ile karşılaştırılarak farklılaşan yönler belirlenecektir. Ayrıca Rize turizminin rakamlarla desteklenen mevcut durumu göz önüne alınarak Rize için çeşitli öneriler geliştirilecektir.

Anahtar Kelimeler: Turizm, turizm verileri, veri kıyaslama, Rize turizmi, Türkiye

\section{Önerilen Atıf:}

Tayfun, A., Aysen, E. ve Akbulut, B.A (2017). Rize İlinin Turizm Göstergelerinin Yıllara Göre Türkiye ile Kıyaslanması: 2009-2015, Türk Turizm Araştırmaları Dergisi, Cilt.1, Sayı.1, ss. 62-75. 


\title{
The Comparison of Rize and Turkey in terms of Tourism Indicators According to the Years: 2009-2015
}

Associate Prof. Dr. Ahmet TAYFUN, Gazi University, Faculty of Tourism. e-mail: tayfun@gazi.edu.tr

Research Assistant Esin AYSEN, Gazi University, Faculty of Tourism. e-mail: esinaysen@gazi.edu.tr

Research Assistant Burcu Ayşenur AKBULUT, Recep Tayyip Erdoğan University, Ardeşen Faculty of Tourism. e-mail: burcuaysenur.akbulut@erdogan.edu.tr

\begin{abstract}
Rize, which is situated in the region of Black Sea of Turkey has a rich tourism potential in terms of the historical and cultural attractions such as traditional houses, stone hampback bridges, mosques, museums. as well as it's natural beauties such as plateaus, hot springs, rivers, falls, lakes, flora and fauna. The usage of tourism resources of Rize and numbers of tourists have been changing within years. The main purpose of the study is to distinguish the situation of Rize in the tourism of Turkey and evaluate it's share of tourism in the axis of Turkey according to the years, of 2009-2015. In this context it will be displayed the change of tourism indicators of Rize in years and compare them with the tourism statistics of Turkey. The tourism of Rize will be compared in terms of the characteristics such as the number of tourist, overnight, purpose of visit, level of income and education with the tourism of Turkey and put forward the points which differ from each other. In addition, by taking into consideration of the current situation of Rize tourism,which is supported with numbers it will be made some suggestions for Rize.
\end{abstract}

Key Words: Tourism, tourism statistics, comparison of data, tourism of Rize, Turkey.

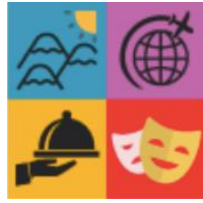

Journal of Turkish Tourism Research Vol. 1, Issue.1, 2017

pp. 62-75.

\section{Suggested Ctitation:}

Tayfun, A., Aysen, E. and Akbulut, B. A (2017). The Comparison of Rize and Turkey in terms of Tourism Indicators According to the Years: 2009-2015, Journal of Turkish Tourism Research, Vol.1, Issue.1, pp. 62-75. 


\section{Gíriş}

Rize, Türkiye'de alternatif turizm ile en fazla öne çıkan çekim merkezlerinden birisidir. Tek başına bu il, bünyesinde çok fazla arz çekiciliğine sahip olmasına rağmen bugüne kadar izlenen ve yürütülen projelerdeki hedef sapmaları nedeniyle turizm sektöründe çeşitliliği ve canlılığı henüz yakalayamamıştır. Kültür ve Turizm Bakanlığı'nca 1990'lı yıllarda başlatılan turizm planlama çalışmalarında, bilhassa Doğu Karadeniz Bölgesi'ndeki mevcut illerin benzerliğinden hareketle bölge bir bütün olarak ele alınmış, illere özgü detay çekiciliklerden turizm adına mahrum kalanlar olmuştur. Rize özelinde yapılabilecek turizm plan ve çalışmalarının merkezinde, yöresel kültürel zenginliğin korunmasına önem verilmesi yerinde olacaktır. Gerek ilin kanayan yarası olan alt yapı sorunlarının giderilmesi, gerek yaylaların turizme kazandırılması için devam eden çalışmalar gerekse de tanıtım faaliyetlerinin artırılması noktasında yöresellikten uzaklaşmayan bir bakış açısı, Rize için elzemdir.

Rize'deki doğal ve kültürel kaynakların turizm için yüksek potansiyel teşkil etmesi, il halkının turizm faaliyetlerinde girişimci bir ruha sahip olması, Türkiye'de artan doğa turizmi talebiyle birleştirildiğinde ilin ekonomik kalkınmasında önemli bir araç olabilecektir (Somuncu, 1991). Zira turizmin yalnızca yerel ekonomi ile doğru şekilde bütünleştirildiği takdirde beklentileri karşılayabileceği ve yöre halkı ile diğer ilgi gruplarına fayda sağlayacağı unutulmamalıdır. Yörede yapılması uygun görülen turizme dönük bu türden çalışmalar ekonomik odaklı görünse dahi esas olumlu yanı, yerli halkın yaşam biçimine ters düşmemesi ve hatta bir zamanlar Anadolu halkının yaşayış biçiminin ta kendisi olmasıdır. Anadolu insanının eskiden bu yana yaz mevsiminde serin ve temiz havası olan yüksek kesimlerde bulunma isteği, bölgede canlandırılmaya çalışılan yayla turizmi ve bu kapsamdaki faaliyetlere temel oluşturmaktadır. Dolayısıyla beklenen odur ki sıcaklığın yükseldiği yaz aylarında yöreyi ziyaret eden hem yerli hem de yabancı turistler açısından yayla turizmine dahil olmak kurtarıcı nitelikte bir faaliyet olacaktır. Yayla turizminin yanı sıra bölgede öne çıkan diğer turizm çeşitleri (doğa, dağ, macera, kırsal turizm vd.) de göz önünde bulundurulduğunda esasen bölge, yerli turistlerin günübirlik ziyaretlerinden çok daha fazlasını hak etmekle birlikte bu turizm çeşitleri, ülkede ve dünyada yükselen turizm trendlerine de karşılık gelebilecek niteliktedir. Tablo 1'de Rize ilinde yer alan turizm merkezleri incelendiğinde yayla, termal+yayla+kış, kıyı ve kış temalarıyla ön plana çıkan merkezler görülmektedir. Bunlardan bir kısmı Kültür ve Turizm Bakanlığınca Kültür ve Turizm Koruma ve Gelişim Bölgesi (KTKGB) ve bir kısmı da öncelikle geliştirilmesi öngörülen Turizm Merkezleri (TM) olarak belirlenmiştir (Kültür ve Turizm Bakanlığı, 2011).

Tablo 1. Rize İli Turizm Merkezleri (2014)

\begin{tabular}{|l|l|l|l|}
\hline \multicolumn{1}{|c|}{ Adı } & \multicolumn{1}{c|}{ İl } & \multicolumn{1}{c|}{ İlçe } & \multicolumn{1}{c|}{ Tema } \\
\hline Rize Anzer KTKGB & Rize & İkizdere & Yayla \\
\hline Rize Anzer TM & Rize & İkizdere & Yayla \\
\hline $\begin{array}{l}\text { Rize Çamlıhemşin Ayder Kaplıcası } \\
\text { TM }\end{array}$ & Rize & Çamlıhemşin & Termal+Yayla+Kış \\
\hline Rize Çamlıhemşin Ayder KTKGB & Rize & Çamlıhemşin & Termal+Yayla+Kış \\
\hline Rize Çayeli TM & Rize & Çayeli & Kiyı \\
\hline Rize İkizdere Ovit Dağı Kış TM & Rize & İkizdere & Kış \\
\hline
\end{tabular}

Kaynak: T.C. Kalkınma Bakanlığı Doğu Karadeniz Projesi Bölge Kalkınma İdaresi Başkanlığı (DOKAB).

Ayder'de turizm odaklı faaliyetler, 1967 yılından itibaren başlamıştır. Yayla içerisinden doğal yolla çıkan sıcak suyun kaplıca tedavisi özelliğinden yararlanmak üzere iki kaplıca binası inşa 
edilmiştir. Bu binaların yapılmasıyla birlikte yöre dışından insanların buraya geldikleri görülmüştür. Bu ise Ayder'de ilk düzenli turizm hareketinin başlangıcı olmuştur (Bakırcl, 1990:45).

Yöre dışından gelenlerin konaklama ihtiyacını karşılamak maksadıyla pansiyon/otel gibi konaklama işletmelerinin sayısı ve bölgedeki yatak kapasitesi giderek artış göstermiştir. Tablo 1'e bakıldığında Rize ilinin turizm bölgelerinde turizm çeşitliliğine olan yatkınlığı dikkat çekmektedir. Özellikle yayla, termal gibi Rize için alışkın olunan turizm türlerinin dışında kış teması, dağ sporları ile ilgilenen kitleler açısından heyecan vericidir. 2640 metre rakımdaki Ovit Dağ 2008 yılında Turizm Bakanlığınca Kış Sporları Merkezi ilan edilmiştir (TÜRSAB, 2014). Buna ilaveten Kaçkar Dağı (3932 m.), Bulut Dağı (3562 m.) ve Altıparmak Dağı (3492 m.)'nda kaya tırmanıcılığı, kar ve buzul tırmanıcılığı gibi Alpinizmin tüm stillerini uygulamak mümkündür (Köksal, 1988).

Rize genelinde sahip olunan konaklama işletmelerinin sayıları Tablo 2. de yer almaktadır.

Tablo 2. Rize İli Konaklama İşletmeleri İstatistiği

\begin{tabular}{|l|c|c|c|c|c|}
\hline & $\begin{array}{c}\text { Bakanlık } \\
\text { İsletme } \\
\text { Belgeli } \\
\text { Konaklama } \\
\text { Tesisleri }\end{array}$ & $\begin{array}{c}\text { Bakanlık } \\
\text { Yatırım } \\
\text { Belgeli } \\
\text { Konaklama } \\
\text { Tesisleri }\end{array}$ & $\begin{array}{c}\text { Belediye } \\
\text { Belgeli } \\
\text { Konaklama } \\
\text { Tesisleri }\end{array}$ & $\begin{array}{c}\text { Konaklama } \\
\text { Tesisleri } \\
\text { Genel } \\
\text { Toplam }\end{array}$ & $\begin{array}{c}\text { Toplam } \\
\text { Seyahat } \\
\text { Acentesi }\end{array}$ \\
\hline Adet & 13 & 6 & 55 & 74 & 18 \\
\hline Oda Sayıs1 & 530 & 516 & 1506 & 2552 & \\
\hline Yatak Sayıs1 & 1064 & 1040 & 3315 & 5419 & \\
\hline
\end{tabular}

Kaynak: Rize Ticaret ve Sanayi Odası

Rize' de turizmin önündeki engellerin başlıcalarını teşkil eden ulaşım ve altyapı sorununa ilişkin çalışmalar kapsamında birçok konaklama ve yeme içme tesisi faaliyete geçirilmiştir. Ayder Yaylası özelinde kış aylarında kapalı bulunan yollar açılmış, kışları faaliyet gösteremeyen konaklama tesislerinin bir kısmı, kışın da hizmet vermeye başlamıştır (Orman ve Su İşleri Bakanlığı, 2013). Tablo 2' de görülmektedir ki 2014 yılında Rize, toplamda 5419 yatak kapasitesine sahip olmuştur. Orman ve Su İşleri Bakanlığı (2013)'nın Rize Doğa Turizmi Master Plan Taslağı'na göre, yerli ve yabancı turistler açısından bölgeyi çekici kılan unsurlar arasında bölgede imkân sağlanan farklı türdeki konaklama faaliyetleri yer almaktadır. Öyle ki Kaçkar Dağları Milli Parkını ziyaret eden turistlerin geliş motivasyonlarında üçüncü sırayı "yaylalarda konaklama" seçeneği almıştır (Atasoy, Reis ve Sancar, 2009:13). Ancak konaklama şekli nasıl olursa olsun nitelikli hizmet sağlanması ve teşviklerin bu yönde olması önemlidir. Bu çalışma kapsamında Rize'nin turizm göstergeleri bakımından Türkiye ile kıyaslanması kısmında da görülecektir ki Rize'ye gelen ziyaretçilerin ortalama kalış süresi Türkiye ortalamasının gerisinde kalmaktadır (Kültür ve Turizm Bakanlığı, 2014). Turistlerin bölgedeki konaklama işletmelerinde kalış sürelerinin uzaması ise yöreye özgü kültürel değerlerin korunması hassasiyetiyle konaklamada konforun sağlanması ile ilişkilidir.

Doğu Karadeniz Bölgesi, hatırı sayılır sayıda korunan alana sahip olmakla birlikte doğal ve kültürel zenginlikleri göz önüne alındığında söz konusu korunan alanların büyüklüğü düşük oranlarda seyretmektedir. Doğu Karadeniz Bölgesinde koruma altına alınan alanlar listesinde Rize ilinden Kaçkar Dağları Milli Parkı ve Tunca Vadisi Tabiat Parkı olmak üzere 2 yer 
bulunmaktır (Kurdoğlu ve Bektaş, 2015:65). Türkiye genelinde bakıldığında ise yüz ölçümüne göre en fazla korunan alana sahip ilk 10 il sıralamasında \%20,25 ile Rize yer almaktadır (Orman ve Su İşleri Bakanlığı, 2011). Türkiye, Doğu Karadeniz Bölgesi ve Rize ilinde korunması gerekli bulunan arkeolojik, kentsel, tarihi ve kentsel arkeolojik sit alanlarının nicelik bakımından dağılımı Tablo 3'te yer almaktadır.

Tablo 3. Rize İli Sit Alanları (2014)

\begin{tabular}{|l|c|c|c|c|c|c|}
\hline İl & $\begin{array}{l}\text { Arkeolojik } \\
\text { Sit Alanı }\end{array}$ & $\begin{array}{l}\text { Kentsel Sit } \\
\text { Alanı }\end{array}$ & $\begin{array}{l}\text { Tarihi } \\
\text { Sit } \\
\text { Alanı }\end{array}$ & $\begin{array}{l}\text { Kentsel } \\
\text { Arkeolojik Sit } \\
\text { Alanları }\end{array}$ & $\begin{array}{l}\text { Diğer Sit } \\
\text { Alanları }\end{array}$ & Toplam \\
\hline Rize & 4 & 1 & 2 & - & 1 & 8 \\
\hline $\begin{array}{l}\text { DOKAB } \\
\text { Bölgesi }\end{array}$ & 184 & 17 & 10 & 2 & 18 & 231 \\
\hline Türkiye & 11.595 & 258 & 154 & 32 & 444 & 12.483 \\
\hline
\end{tabular}

Kaynak: T.C. Kalkınma Bakanlığı Doğu Karadeniz Projesi Bölge Kalkınma İdaresi Başkanlığı (DOKAB).

Çalışmada Rize Turizm İstatistikleri Türkiye turizm istatistikleri ile; gelen turist sayısı, geceleme miktarı, turistlerin ziyaret amacı, gelir ve eğitim düzeyleri açısından kıyaslanmış ve 2009-2015 yılları arasında Rize'nin söz konusu değişkenler açısından Türkiye turizmi ile ayrışan ve birleşen noktaları rakamlarla belirlenmeye çalışılmıştır. Burada Türkiye geneli ile kıyaslanan Rize'nin esas olarak turizm profilini çıkarmak, yükselen turizm trendlerine ne denli yakın durmakta olduğunu görebilmek, yeni arayışlar ile farklı turistik tecrübelere sahip olma ve macera odaklı tatil anlayışını benimseyen ziyaretçiler için bir alternatif olabilmesi yönünde öneriler geliştirmek hedeflenmektedir.

\section{RIZZE İLI'NİN TURIZM GÖSTERGELERINNINN YILLARA GÖRE TÜRKIYYE İLE KIYASLANMASI: 2009-2015}

Rize'nin sahip olduğu turizm kaynaklarının kullanımı ve bölgeye gelen turistler yıllar içinde değişim göstermektedir. Bu bölümde araştırmaya konu olan Rize ve Türkiye'nin turizm göstergelerinin yıllara göre Türkiye ile kıyaslanması amacıyla gelen turist sayısı, geceleme durumları, turistlerin ziyaret amacı, turistlerin geliri, turistlerin eğitim düzeyleri ile ilgili veriler yer almaktadir.

\section{Gelen Turist Sayısı}

Rize ve Türkiye'ye gelen turistlerin sayıs1; yerli, yabancı ve toplam olmak üzere Tablo 4'te görülmektedir. Türkiye'ye gelen toplam turist sayısı 2009 yılında 32.006 .149 iken, 2015 yılında 41.617.530' a yükselerek yedi yıllık süreçte $\% 30$ artış göstermiştir. Rize'nin turist sayısı gelişimine bakıldığında 2009 yılında 496.546 iken, 2015 yılında bu sayı 690.348 olarak yedi yıllık süreçte \% 39 artış göstermiştir. Bu açıdan Rize'nin turist sayısındaki artış oranının Türkiye'ye göre fazla olduğu görülmektedir. 
Tablo 4. Gelen Turist Sayısı

\begin{tabular}{|c|c|c|c|c|c|c|c|}
\hline & \multicolumn{3}{|c|}{ Turist Say1S1 (RiZE) } & & \multicolumn{3}{c|}{ Turist Say1S1 (TÜRKİYE) } \\
\hline YIL & YERLİ & YABANCI & TOPLAM & YIL & YERLİ & YABANCI & TOPLAM \\
\hline $\mathbf{2 0 0 9}$ & 437817 & 58729 & 496546 & $\mathbf{2 0 0 9}$ & 4658172 & 27347977 & 32006149 \\
\hline $\mathbf{2 0 1 0}$ & 489731 & 69407 & 559138 & $\mathbf{2 0 1 0}$ & 4517091 & 28510852 & 33027943 \\
\hline $\mathbf{2 0 1 1}$ & 509911 & 61217 & 571128 & $\mathbf{2 0 1 1}$ & 4826800 & 31324528 & 36151328 \\
\hline $\mathbf{2 0 1 2}$ & 524021 & 61675 & 585696 & $\mathbf{2 0 1 2}$ & 5121457 & 31342464 & 36463921 \\
\hline $\mathbf{2 0 1 3}$ & 581465 & 68417 & 649882 & $\mathbf{2 0 1 3}$ & 5398752 & 33827474 & 39226226 \\
\hline $\mathbf{2 0 1 4}$ & 615053 & 71116 & 686169 & $\mathbf{2 0 1 4}$ & 5564784 & 35850286 & 41415070 \\
\hline $\mathbf{2 0 1 5}$ & 616889 & 73459 & 690348 & $\mathbf{2 0 1 5}$ & 6025370 & 35592160 & 41617530 \\
\hline
\end{tabular}

Kaynak: Türkiye İstatistik Kurumu (www.tuik.gov.tr)

Grafik 1'de görüleceği üzere Rize'nin gelen turist sayısı Türkiye ile kıyaslandığında turistlerin yerli ve yabancı olmalarına göre bir farklılık ortaya çıtığı görülmektedir. Rize'ye gelen yabancı turist sayısında 2009-2015 yılları arasında dalgalanmalar yaşanmakla birlikte 2011 yılı itibariyle sürekli artış; yerli turist sayısında ise istikrarlı bir artış olmuştur. Bu durum, Rize'ye gelen turistlerin \% 85'inden fazlasının yerli turist olması neticesini doğurmuştur.

Türkiye verilerine bakıldığında ise Rize'nin aksine yerli turist sayısındaki artış ve azalışlar, 2011 yılından itibaren yerini istikrarlı bir artışa bırakmış, yabancı turist sayısı ise en başından itibaren (2009) sürekli artış göstermiştir.

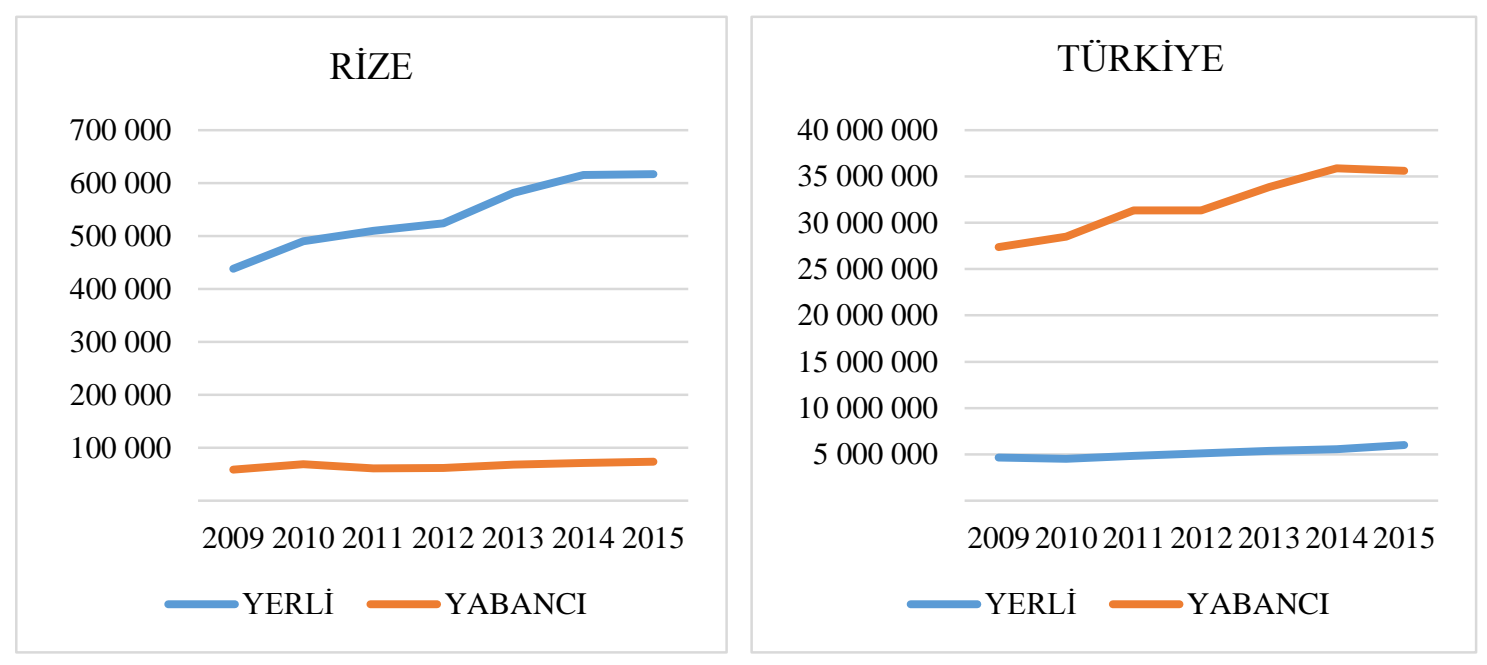

Grafik 1. Gelen Turist Say1S1, 2009-2015 


\section{Turistlerin Geceleme Durumları}

Tablo 5. Yerli ve Yabancı Turistlerin Konaklama Tesisi Türüne Göre Geceleme Durumları

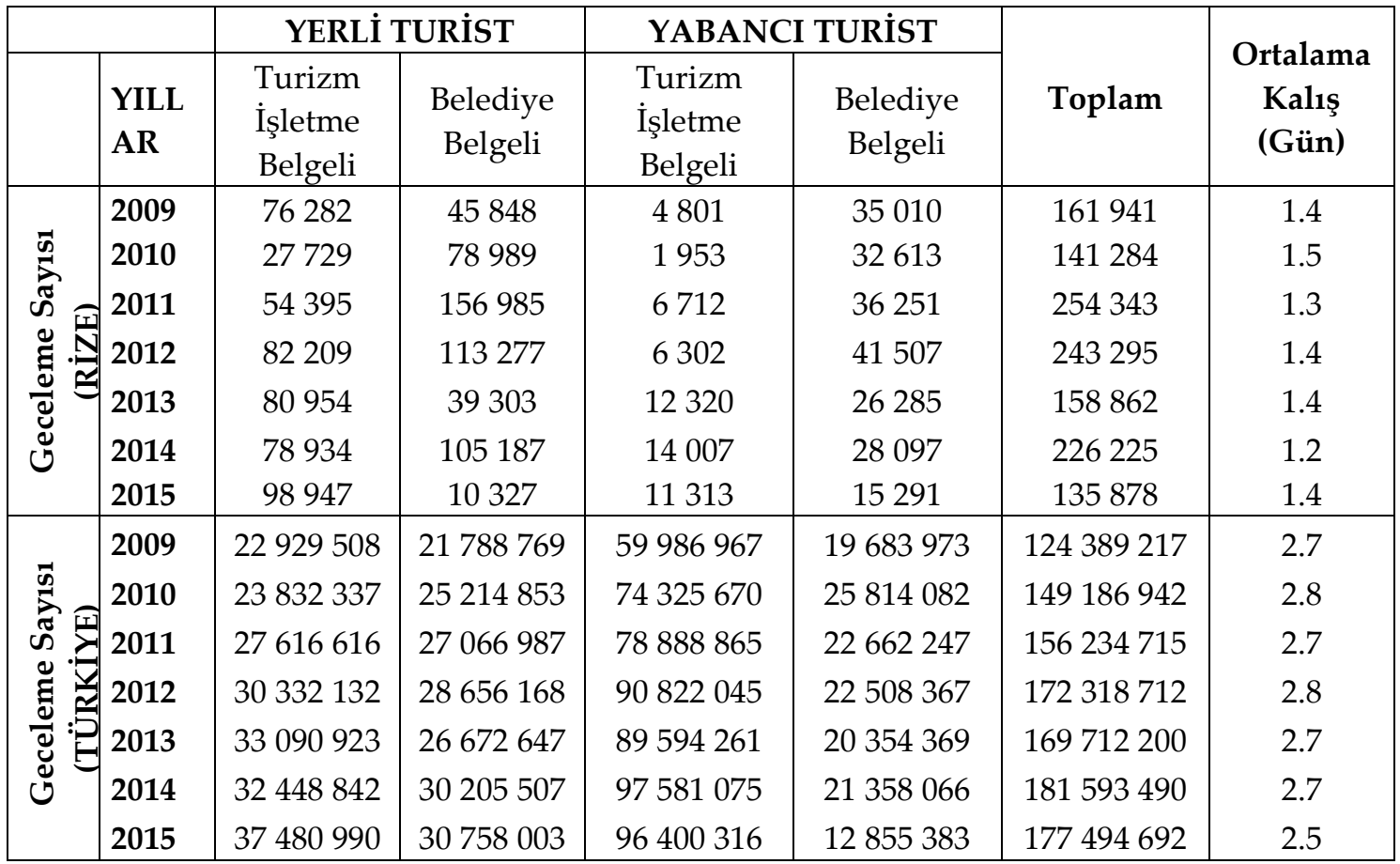

Kaynak: Kültür ve Turizm Bakanlığ1

Yerli ve yabancı ayırt etmeksizin gelen turistlerin Rize'de daha fazla vakit geçirerek konakladıkları gün sayısını artırmak, zincirleme bir takım sorunların ortadan kalkması ile alakalıdır. Bilhassa devam eden yol yapım çalışmalarının (Yeşil Yol) süratle tamamlanması, güzergah üzerindeki turizm merkezlerinde otel, motel, pansiyon ve restoranların sayısındaki artışın da önünü açacaktır (Sümer, 2014:168). Bu gelişmeler neticesinde Rize'yi ziyaret eden turistlerin geceleme sayısında yükseliş yaşanması beklenmektedir. Tablo 5. incelendiğinde hem Rize hem de Türkiye'yi ziyaret eden yerli ve yabancı turistlerin geceleme sayılarının turizm işletme ve belediye belgeli tesislere göre yıllar içerisinde değişkenlik ve farklılık gösterdiği görülmektedir. $\mathrm{Bu}$ nedenle geceleme sayışları üzerinden yorum yapmak çok isabetli olamayacağından turistlerin Rize ve Türkiye'deki ortalama kalış sürelerine odaklanmak gerekli görülmektedir. 2009-2015 yılları arasında Rize'ye gelen turistlerin ortalama kalış süresi en fazla 1.5 gün seviyesine ulaşabilmiştir. 2010 yılında ulaşılan bu seviye, ilerleyen yıllarda ne yazık ki tekrar yakalanamamıştır. Rize'de turistlerin ortalama kalış süreleri Türkiye'ye gelenler ile kıyaslandığında neredeyse yarısı kadardır. Diğer bir ifade ile Türkiye'de ortalama kalışın 2.8 gün olduğu 2012 yılında Rize'de ortalama kalış (aynı yıl) 1.4 gün olmuştur. Diğer yıllardaki farlılıklar da aşağı yukarı buna benzer düzeyde olmuştur. 

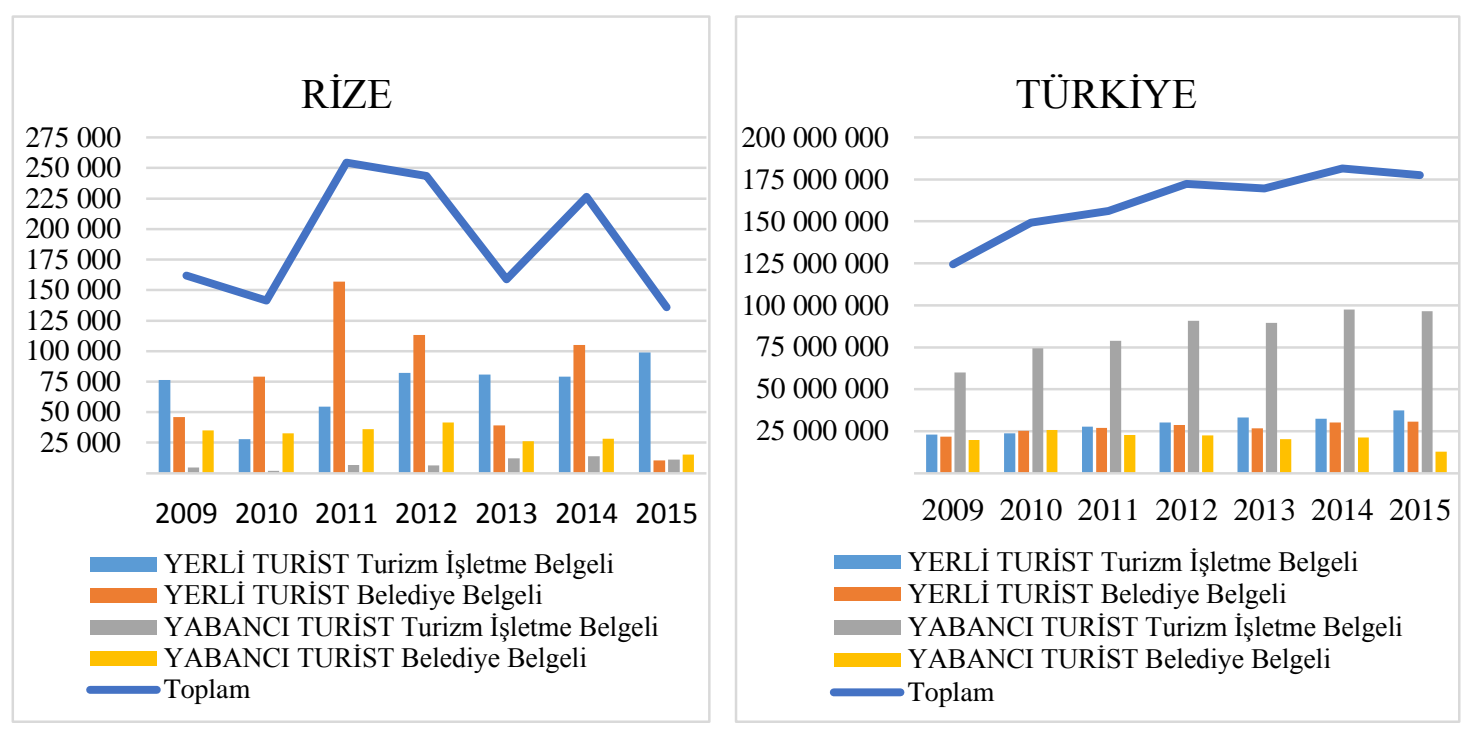

Grafik 2. Turistlerin Konaklama Tesisi Türüne Göre Geceleme Durumları, 2

Kaynak: Türkiye İstatistik Kurumu (www.tuik.gov.tr).

Grafik 2 incelendiğinde Rize'ye gelen yerli ve yabancı turistlerin daha ziyade belediye belgeli konaklama işletmelerinde geceledikleri, Türkiye' de ise yabancı turistlerin turizm işletme belgeli tesislerde daha fazla geceledikleri dikkat çekmektedir. Rize'ye gelen turistlerin toplam geceleme miktarı söz konusu yıllar arasında oldukça inişli çıkışlı bir seyir izlerken Türkiye'ye gelenlerin geceleme sayıları daha istikrarlı bir duruş sergilemektedir.

\section{Turistlerin Ziyaret Amac1}

Her yıl milyonlarca turist çeşitli amaçlarla Türkiye'yi ziyaret etmektedir. Gezi, eğlence, sportif ve kültürel faaliyetler, akraba ve arkadaş ziyareti, eğitim, staj, sağlık ve tıbbi nedenler, dini/hac, alışveriş, transit ve iş amaçlı olmak üzere Rize ve Türkiye'de turizm faaliyetlerine katılan turistlerin yıllara göre değişimi Tablo 6'da yer almaktadır.

Yıllar itibariyle turistlerin Rize'ye en çok akraba ve arkadaş ziyareti amacıyla geldiği, Türkiye'yi ise gezi, eğlence, sportif ve kültürel faaliyetler nedeniyle ziyaret ettikleri görülmektedir. Söz konusu yıllar arasında Türkiye'yi dini/hac sebebiyle ziyaret eden turistlerin sayısı en az olmakta; Rize'yi ise dini/hac sebebi ile ziyaret eden turist bulunmamaktadır.

Grafik 3'te görüldüğü üzere Rize'ye ve Türkiye'ye gelen turistlerin ziyaret amaçları değişkenlik göstermektedir. Rize'ye gelen turist sırasıyla akraba ve arkadaş ziyareti, gezi, eğlence, sportif ve kültürel faaliyetler, alışveriş amaçlarıyla gelirken, Türkiye'ye sırasıyla gezi, eğlence, sportif ve kültürel faaliyetler, akraba ve arkadaş ziyareti ve iş amaçlarıyla gelmektedir. 

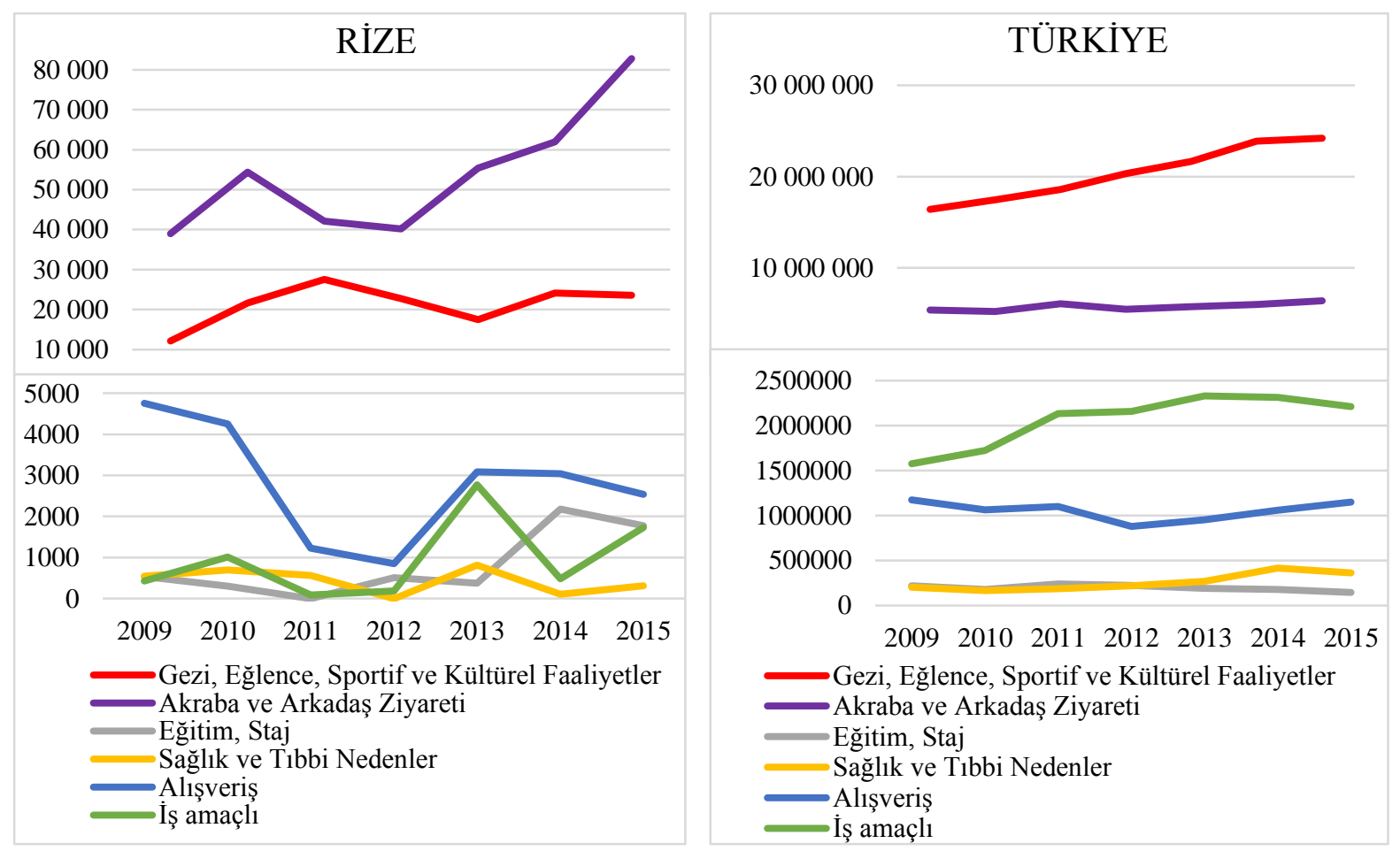

Grafik 3. Turistlerin Zivaret Amac1, 2009-2015

\section{Turistlerin Geliri}

Turizm, temelde bir tüketim davranışıdır. Türkiye'ye gelen turistlerin gelir düzeyleri turizm faaliyetlerine katılmalarını ve harcamalarını etkilemesi açısından önemli bir turizm göstergesidir.

Tablo 7. Turistlerin Geliri

\begin{tabular}{|c|c|c|c|c|c|c|c|}
\hline & Yillar & $\begin{array}{c}\text { Çok } \\
\text { Düşük }\end{array}$ & Düşük & Orta & Yüksek & $\begin{array}{c}\text { Çok } \\
\text { Yüksek }\end{array}$ & Toplam \\
\hline \multirow{7}{*}{ 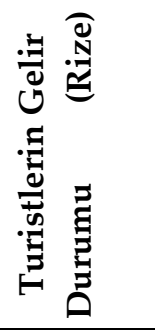 } & 2009 & 1634 & 82622 & 95935 & 7574 & 201 & 187966 \\
\hline & 2010 & 252 & 230422 & 54945 & 6321 & 0 & 291940 \\
\hline & 2011 & 247 & 215009 & 78106 & 3995 & 727 & 298084 \\
\hline & 2012 & 1233 & 116673 & 38531 & 3480 & 0 & 159917 \\
\hline & 2013 & 235 & 142676 & 54226 & 6015 & 634 & 203786 \\
\hline & 2014 & 489 & 128050 & 117295 & 4837 & 149 & 250820 \\
\hline & 2015 & 386 & 208169 & 215481 & 7328 & 20542 & 451906 \\
\hline \multirow{7}{*}{ 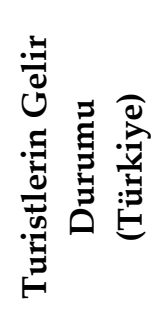 } & 2009 & 501434 & 2771021 & 18871966 & 4205497 & 463328 & 26813246 \\
\hline & 2010 & 478288 & 3211711 & 19222385 & 4378427 & 494083 & 27784894 \\
\hline & 2011 & 563530 & 3900191 & 20841571 & 4579306 & 510099 & 30394697 \\
\hline & 2012 & 556389 & 3657698 & 20977531 & 4602561 & 509353 & 30303532 \\
\hline & 2013 & 506453 & 4270824 & 21978092 & 5114722 & 560683 & 32430774 \\
\hline & 2014 & 526108 & 3743592 & 24704938 & 5445667 & 610991 & 35031296 \\
\hline & 2015 & 545718 & 3347808 & 25376199 & 5772898 & 801863 & 35844486 \\
\hline
\end{tabular}

Kaynak: Türkiye İstatistik Kurumu (www.tuik.gov.tr) 
Tablo 7'den anlaşılacağı üzere Türkiye'yi en fazla, orta gelir düzeyine sahip turistler ziyaret etmektedir. Rize'ye gelenler arasında ise, düşük gelir düzeyine sahip olan turistlerin sayıca üstünlüğü dikkat çekmektedir. Türkiye'de çok yüksek gelir düzeyine sahip turistlerin sayısı, orta ve yüksek gelir düzeyine sahip turistlere oranla az olmasına rağmen sayıları yıllar geçtikçe artmaktadır. Ancak Rize'ye gelen turistler arasında çok yüksek gelire sahip olanlar son sıralarda yer almaktadır. Dolayısıyla Türkiye'deki ivmeyi Rize'de de yakalayabilmek ve yüksek gelirli turistin ilgisini bu ile çekebilme yönündeki çalışmalara ağırlık vermek yerinde olacaktır.

Grafik 4'te görüldüğü üzere son yıllarda, Rize'ye gelen turistlerden gelir düzeyleri düşük ve
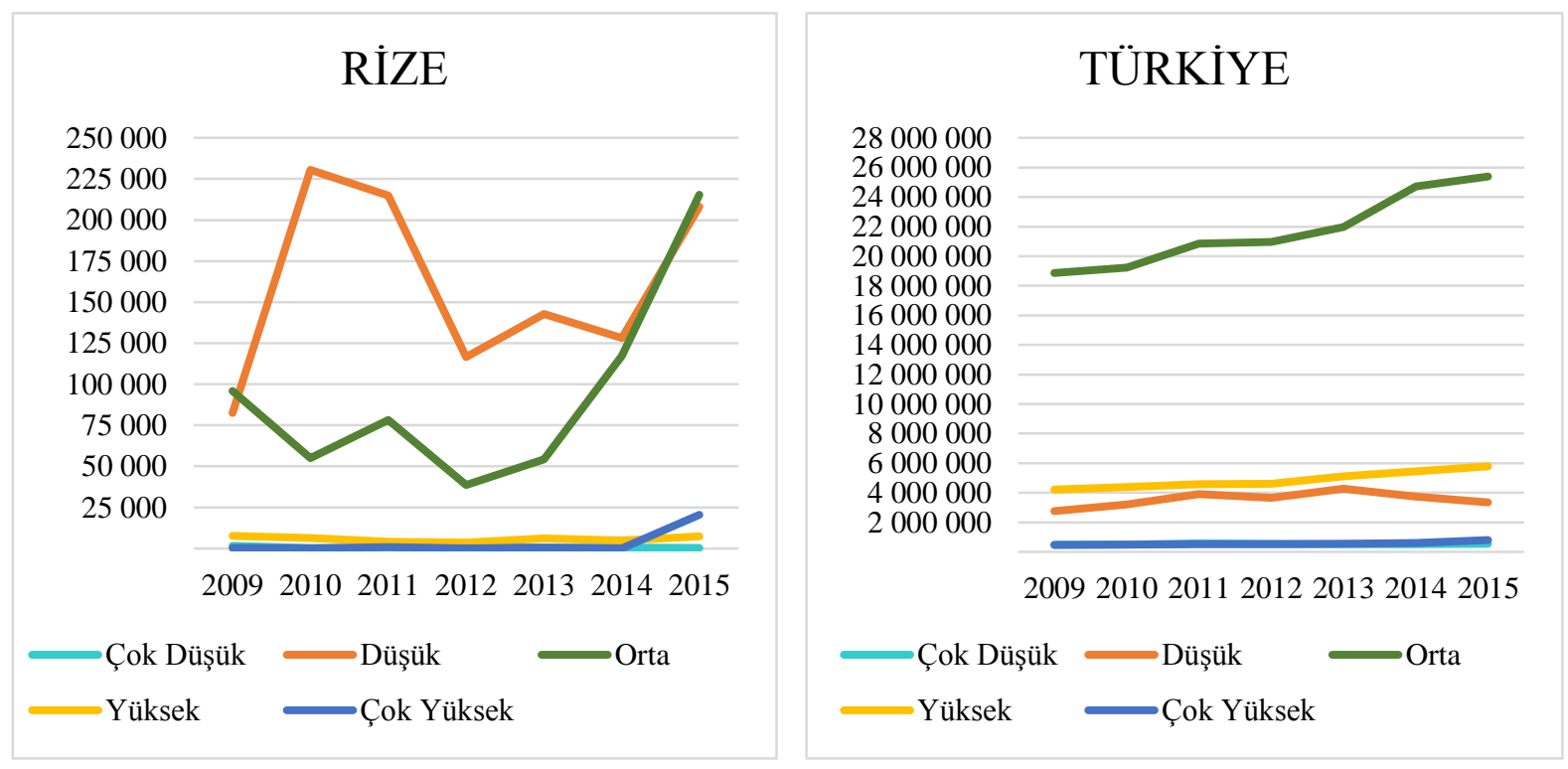

Grafik 4. Turistlerin Geliri, 2009-2015

orta olanların yükselişe geçtiği ve birbirine yaklaştığı söylenebilir. Yapılan araştırmalar; turistlerin gelir düzeyinin, turizm eğilimini olduğu kadar gezinin biçimini ve niteliğini de etkilediğini öne sürmektedir. Düşük gelir grubundaki ailelerin, tatillerinde daha ziyade akraba ve arkadaş yanında kaldığı, yüksek gelir grubudakilerin ise lüks otel konaklamalarını diğger gelir gruplarına nazaran daha çok tercih ettiklerini söylemek mümkündür (Doğan, 2004:50). Tablo 7 'deki veriler değerlendirildiğinde, her ne kadar Türkiye'ye gelen turistlerin gelir durumları iyi (orta, yüksek, çok yüksek) olsa dahi Türkiye'de yaptıkları harcamaların düştügü görülmektedir. Öyle ki Türkiye'ye gelen turistlerin ortalama harcamaları 2014 yılında 828 dolar iken bu sayı 2015'de 756 dolara düşmüştür (Türkiye İstatistik Kurumu, 2016). Bu açıdan bakıldığında, gelir düzeyi yüksek turistin giriş yapması kadar önemli başka bir husus var ise o da bu gelir grubunda yer alan turistin Türkiye' de yaptığı harcama miktarının artırılmasına yönelik unsurların dikkate alınması gerekliliğidir.

\section{Turistlerin Eğitim Düzeyleri}

Türkiye'ye ve Rize'ye gelen turistlerin eğitim düzeyleri ile ilgili veriler Tablo 8'de yer almaktadır. Gelen turistlerin eğitim düzeylerine ilişkin veriler değerlendirildiğinde Rize'ye gelen turistlerin \% 70'ini lise ve dengi okul mezunu olanlar oluşturmakta; Türkiye'ye gelenlerin ise \% 36'sının fakülte ve yüksekokul, \% 31'inin lise ve dengi okul mezunu olduğu görülmektedir. Rize'ye gelen turistler arasında yüksek eğitim düzeyine sahip olanların sayıca azınlıkta olduğu görüllmektedir. 
Yapılan araştırmalar genellikle eğitim düzeyi ile turizm hareketlerine katılma arasında doğru orantı olduğunu ortaya koymuştur.. Eğitim düzeyi arttıkça turizme katılma eğiliminin de arttığ söylemek doğru olacaktır. Eğitim düzeyi ile seyahat sıklığı arasındaki ilişki; eğitimin yüksek gelir sağlaması, yabancı dil bilgisinin dış ülkelere gezi eğilimin artırması, eğitimin bilimsel ve kültürel amaçlı gezi eğilimini artırması gibi etmenlerden kaynaklanmaktadır (Doğan, 2004:47).

Grafik 5'te görüleceği üzere Türkiye'ye gelen turistlerin Rize'ye gelen turistlere oranla eğitim düzeylerinin daha yüksek olduğu söylenebilmektedir. Yukarıda açıklandığı üzere eğitim düzeyi ve seyahat etmek sıklığı arasındaki doğru orantı dikkate alındığında eğitimli turistler; seyahat kararı alırken daha bilinçli tercihler yapma ve olası olumsuzluklara karşı önlem alma yönelimleri nedeniyle gidilecek bölge ile ilgili detaylı bilgi edinmek istemektedir. 21. yy'da gerek satın alma kararını etkileyen gerekse imaj oluşumunda önemli bir işlevi olan bilgi kaynaklarından internet, önemli bir hale gelmiştir. Turizmde ağızdan ağıza iletişim; email, web siteleri, bloglar, sanal topluluklar, yorum siteleri ve sohbet odaları yoluyla internet üzerinden sağlanmakta ve turistler gidilecek bölgeyle ilgili bilgileri bu sosyal ağlardan edinmektedir. Bu açıdan Rize'nin pazarlama stratejilerini geliştirilmesi aşamasında internet yoluyla iletişimin etkin şekilde kullanması yerinde olacaktır.

Tablo 8. Turistlerin Eğitim Düzeyleri

\begin{tabular}{|c|c|c|c|c|c|c|c|}
\hline & Yillar & $\begin{array}{c}\text { Okur } \\
\text { Yazar } \\
\text { Değil/ Bir } \\
\text { Okul } \\
\text { Bitirmedi }\end{array}$ & $\begin{array}{l}\text { İlköğretim } \\
\text { / Ortaokul }\end{array}$ & $\begin{array}{c}\text { Lise ve } \\
\text { Dengi Okul }\end{array}$ & $\begin{array}{c}\text { Fakülte, } \\
\text { yüksek } \\
\text { okul }\end{array}$ & $\begin{array}{l}\text { Yüksek } \\
\text { lisans, } \\
\text { doktora }\end{array}$ & Toplam \\
\hline \multirow{7}{*}{ 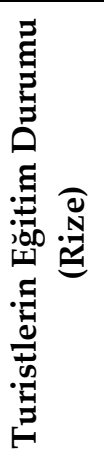 } & 2009 & 0 & 16965 & 144939 & 22395 & 3667 & 187966 \\
\hline & 2010 & 1623 & 43947 & 204199 & 40617 & 1554 & 291940 \\
\hline & 2011 & 1773 & 32039 & 233261 & 28841 & 2171 & 298085 \\
\hline & 2012 & 1481 & 55643 & 89019 & 12784 & 990 & 159917 \\
\hline & 2013 & 1499 & 51516 & 116810 & 29623 & 4338 & 203786 \\
\hline & 2014 & 422 & 52568 & 167775 & 28038 & 2018 & 250821 \\
\hline & 2015 & 237 & 85265 & 334303 & 26972 & 5130 & 451907 \\
\hline \multirow{7}{*}{ 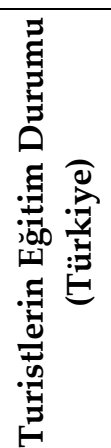 } & 2009 & 755930 & 5991784 & 9409439 & 7995867 & 2660227 & 26813247 \\
\hline & 2010 & 822247 & 5686104 & 9220224 & 8890228 & 3166089 & 27784892 \\
\hline & 2011 & 879112 & 5875231 & 10048618 & 9884089 & 3707653 & 30394703 \\
\hline & 2012 & 398023 & 5519800 & 8989414 & 11662276 & 3734018 & 30303531 \\
\hline & 2013 & 305304 & 5580423 & 9822725 & 12796709 & 3925613 & 32430775 \\
\hline & 2014 & 301131 & 5613038 & 10644788 & 14410957 & 4061383 & 35031297 \\
\hline & 2015 & 152191 & 6011131 & 10102001 & 12969981 & 6609181 & 35844485 \\
\hline
\end{tabular}

Kaynak: Türkiye İstatistik Kurumu (www.tuik.gov.tr) 


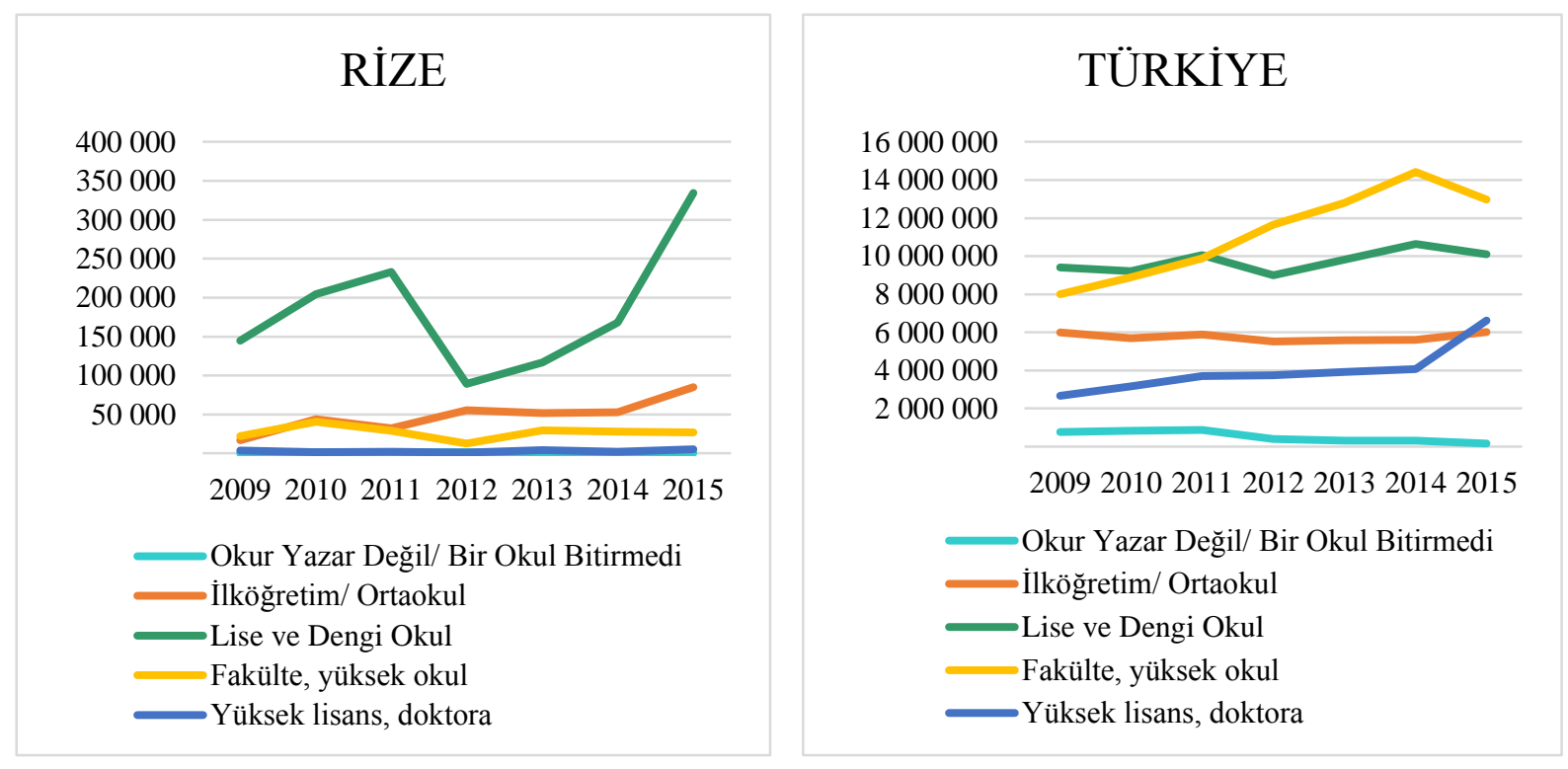

Grafik 5. Turistlerin Eğitim Düzeyleri, 2009-2015

\section{SONUÇ VE ÖNERİLER}

Rize ili; tarihi, kültürel zenginlikler ve doğal güzellikler ile bunların çeşitlendirilebilme potansiyeline sahip olması dolayısıyla yerli ve yabancı turistler için giderek daha cazip bir turizm destinasyonu halini almaktadır. Bölgenin bünyesinde barındırdığı doğal çekicilikler, insan yapımı çalışma ve çabalar ile desteklenmeye muhtaçtır. Bu bağlamda ilde sınırlı olan kaliteli konaklama olanaklarının artırılması ve turizm yatıımcılarını Rize' ye çekmek için daha fazla çaba gösterilmesine ihtiyaç duyulmaktadır. Rize İl Kültür ve Turizm Müdürlüğü gerek katıldığı fuarlarda gerekse de yapılan ağırlama faaliyetlerinde, turizmin ekonomiye katkı sağlamasının birinci kaidesi olan, gelen turisti daha fazla gün konaklatabilmek yönündeki çalışmalarını titizlikle ele almalıdır.

Rize'nin turizm göstergelerinin Türkiye ile kıyaslanması sonucunda ortaya çıkan sonuçlar değerlendirildiğinde Türkiye'ye gelen turist sayısının yedi yıllık süreçte $\% 30$ artış gösterdiği bununla beraber Rize'ye gelen turist sayısının aynı süreçte \% 39 artış gösterdiği görülmüştür. Dolayısıyla 2009-2015 yılları arasında Rize'nin turist sayısındaki artış yüzdesinin Türkiye'ye oranla yüksek olduğu sonucuna ulaşılmıştır. Rize'de var olan turizm potansiyelinin çeşitli nedenlerle ortaya çıkartılmaya başlanmasıyla birlikte bölgeye olan iç turizm talebinde artış olduğu gözlenmiştir. Söz konusu yıllar arasında yöreye gelen turist sayılarına bakıldığında bu durumu destekler nitelikte bir tablo ortaya çıkmaktadır. Rize'ye gelen turist sayısı Türkiye ile kıyaslandığında ise turistlerin yerli ve yabancı olma durumlarına göre bir farklılık ortaya çıkmaktadır. Rize'de gelen turistlerin \% 85'inden fazlası yerli turistten oluşmakta iken Türkiye'de bu durum yabancı turistin bariz çoğunluğu şeklinde kendini göstermektedir.

Turistlerin ziyaret amaçları değerlendirildiğinde Rize'ye gelen turistin en çok akraba ve arkadaş ziyareti amaciyla geldiği, Türkiye' yi ziyaret eden turistlerin ise gezi, eğlence, sportif ve kültürel faaliyetler nedeniyle geldiği görülmektedir. Hem Türkiye hem de Rize'ye dini/hac ziyareti amacıyla gelenler, sayıca en az olan grubu oluşturmuştur. Rize ilinin öne çıkan arz kaynaklarından birini oluşturan kaplıcalar, ilin sağlık turizminde arzu edilen seviyelere yükselmesi için önemli bir çekicilik unsurudur. Ancak Rize'ye gelen turistlerin ziyaret amaçları 
irdelendiğinde nedenler ile gelenlerin sayılarındaki düşüklük dikkat çekmektedir. Öyle ki bazı yıllarda (2012) Rize'yi sağlık ve tıbbi amaçlı ziyaret eden turist bulunmamıştır. Önümüzdeki yılları takiben Rize ilinin sahip olduğu Ayder Kaplıcaları ve bunların tedavi edici özelliklerinden daha fazla faydalanılması ve bunun sonucunda yöreye sağlı//tıbi nedenlerle gelenlerin sayısında artış sağlanmasına yönelik çalışmalar yapılarak kaplıca özelliği taşıyan merkezlerin tanıtım ve pazarlama faaliyetlerine ağıllık verilmesi gerekmektedir.

Türkiye'ye gelen turistlerin çoğunun orta düzeyde gelire sahip oldukları görülürken, Rize'ye düşük gelir düzeyine sahip olanların geldiği görülmektedir. Son yıllarda, Rize'ye gelen turistlerin gelir düzeyleri düşük ve orta olanların yükselişe geçtiği ve yer yer rakamların birbirine yaklaştığ görülmektedir. Ne var ki Rize'ye gelen turistler arasında çok yüksek gelir düzeyine sahip olanlar sayıca azınlığı oluşturmaktadır. Bu durum göz önünde bulundurulduğunda Rize, gelir düzeyi yüksek turisti çekebilme noktasında Türkiye'nin gerisinde kalmaktadır. Yüksek gelir grubuna hitap eden aktivitelerinin özel ilgi turizmi kapsamında bölgede canlandırılarak hedef kitleyi bölgeye çekmek mümkün olabilecektir.

Gelen turistlerin eğitim düzeylerine göre dağılımlarında Rize' ye gelen turistlerin \% 70'ini lise ve dengi okul mezunu olanlar oluşturmakta; Türkiye'ye gelenlerin ise \% 36'sının fakülte ve yüksekokul, \% 31'inin lise ve dengi okul mezunu olduğu görülmektedir. Türkiye'ye gelen turistlerin Rize'ye gelen turistlere nazaran eğitim düzeylerinin daha yüksektir. Gelir durumında olduğu gibi eğitim düzeyi de turistlerin seyahat etme sıklığ 1 üzerinde olumlu bir etkiye sahiptir. Eğitim seviyesi yükselen turistlerin çevresine, ülkesine ve diğer ülkelere olan ilgi ve merak seviyesi artacağından bu durum daha sık seyahat etmesi ile sonuçlanacaktır. Rize ilinde kongre ve bilimsel faaliyetlere ağırlık verilerek eğitim düzeyi yüksek turistin burada ağırlanması yolu ile hem kongre turizmine bir zemin oluşturmak hem de bu amaçla gelen turistlere yöreyi tanıtarak bir sonraki ziyaret sebeplerini çeşitlendirmek mümkün olabilecektir.

Mevcut göstergelerden elde edilen sonuçlardan hareketle Rize iline çeşitli amaçlar ile ziyarete gelen, eğitim ve gelir düzeyi birbirinden farklı yerli ve yabancı turistlerin yöredeki ortalama kalış süresinin, Türkiye ortalamasının altında olduğu görülmüştür. Bu durumun, bir bölgede turizmin gelişmesinin ön koşulu olan alt ve üst yapı olanakları bakımından Rize ilinin yetersiz kalışından kaynaklanması muhtemeldir. Bu halin bilincinde olan yerel yönetimler gerekli çalışmalara başlamış ancak Rize halkı ve medyanın da dile getirdiği üzere çalışmalara gereken hız kazandırılamamıştır. Tamamlanamayan temel düzeydeki alt yapı çalışmaları, üst yapının oluşturulmasına da engel olmakta ve bölgenin turizm sektöründen hak ettiği kar düzeyine ulaşması gecikmektedir. Her geçen sene daha fazla misafir ağırlayabilecek ve gelen turistin ilgisini canlı tutarak daha çok geceleme yapmasını sağlayayacak doğal çekiciliklere sahip Rize ilinde uzunca süredir var olan olumsuzlukların giderilmesi, mevcut potansiyelin beşeri dokunuşlarla destelenerek onlara turistik nitelik kazandırılması ile bölge turizminin canlanması ve gelişmesi beklenmektedir.

\section{KAYNAKLAR}

Atasoy, M., Reis, S. ve Sancar, C. (2009). Sürdürülebilir Turizm Gelişmesi ve Yayla Turizmi: Ayder Yaylası, TMMOB Harita ve Kadastro Mühendisleri Odası, 12. Türkiye Harita Bilimsel ve Teknik Kurultayı, Ankara, 11 - 15.

Bakırcı, M. (1990). Doğu Karadeniz'de Yayla Turizmi. Turizm Dünyası Dergisi, 2(15):45-48.

Doğan, H. Z. (2004). Turizmin Sosyo-Kültürel Temelleri. Ankara: Detay Yayıncllık. 
Köksal, A. (1988). Karadeniz Bölgesinin Turizm Coğrafyası. Birinci Tarih Boyunca Karadeniz Kongresi Bildirileri Samsun. 13-17 Ekim 1988.

Kurdoğlu, O. ve Bektaş, V. (15-17 Ekim, 2015). Korunan Alanlarda Turizmden Kaynaklanan Sorunlar: Kaçkar Dağları Milli Parkı Örneği. IV. Ormancılıkta Sosyo-Ekonomik Sorunlar Kongresi, Trabzon.

Kültür ve Turizm Bakanlığı (2011). KTKGB ve Turizm Merkezleri. Yatırım ve İşletmeler Genel Müdürlüğü. 22.08.2016 tarihinde http://www.ktbyatirimisletmeler.gov.tr/TR,9669/ktkgbve-turizm-merkezleri.html adresinden alınmıştır.

Kültür ve Turizm Bakanlığı Yatırım ve İşletmeler Genel Müdürlüğü (2014). Konaklama, Tesise Geçiş ve Geceleme Formları 20.08.2016 tarihinde http://www.ktbyatirimisletmeler.gov.tr/TR,9871/konaklama-tesise-gelis-ve-gecelemeformlari.html adresinden alınmıştır.

Orman ve Su İşleri Bakanlığı, (2011). Korunan Alanlar ve İklim Değişikliği Türkiye Ulusal Stratejisi. 20.08.2016 tarihinde http://www.tr.undp.org/content/turkey/tr/home/library/environment_energy/protectedar eas.html adresinden alınmıştır.

Orman ve Su İşleri Bakanlığı, (2013). Rize Doğa Turizmi Master Plan Taslağı. Doğa Koruma ve Milli Parklar Genel Müdürlüğ̈̈, Ankara.

Rize Ticaret ve Sanayi Odası (2016). Rize hakkında. 20.08.2016 tarihinde http://rizetso.org.tr/ adresinden alınmıştır.

Somuncu, M. (1991). Rize-Ayder Yaylasında Turizm, Ankara Üniversitesi Dil ve Tarih-Coğrafya Fakültesi Dergisi, 1(4):268.

Sümer, G. Ç. (2014). Rize'de Kentleşme Süreci. Ekonomik ve Sosyal Araştırmalar Dergisi, 10 (1):163183.

T.C. Kalkınma Bakanlığı Doğu Karadeniz Projesi Bölge Kalkınma İdaresi Başkanlığı (DOKAB). (2014). Rize il istatistikleri 2014. İzleme ve Değerlendirme Koordinatörlüğü, Giresun.

TÜRSAB (2014). Kış Turizmi Raporu. 19.08.2016 tarihinde http://www.tursab.org.tr/dosya/12196/tursab-kis-turizmi-raporu119314251845-

1_12196_3978793.pdf adresinden alınmıştır. 